\title{
TPP, RCEP and the Future of Copyright Norm-setting in the Asian Pacific
}

\author{
Peter $\mathrm{K} \mathrm{Yu}^{1}$
}

\section{Introduction}

The past decade has seen two mega-regional intellectual property norm-setting exercises focusing on countries in the Asian Pacific region. The first was part of the effort to establish the Trans-Pacific Partnership ${ }^{2}$ (TPP), a mega-regional pact that was intended to cover ' $40 \%$ of global GDP [gross domestic product] and some 30\% of worldwide trade in both goods and services'. ${ }^{3}$ The negotiations surrounding this partnership ran from 15 March 2010 until the signing of the final agreement on 4 February 2016. In January 2017, shortly after the inauguration of the Trump Administration, the United States withdrew from the TPP,

\footnotetext{
1 Copyright (ㅇ 2018 Peter K Yu. Professor of Law, Professor of Communication and Director, Center for Law and Intellectual Property, Texas A\&M University. An earlier version of this chapter was delivered as the keynote opening address at the 2016 Meeting of the Asian Pacific Copyright Association at the Faculty of Law of the University of Hong Kong. The author is grateful to the participants for valuable comments and suggestions. The chapter draws on research from the author's earlier articles in the SMU Science and Technology Law Review and the Vanderbilt Journal of Transnational Law.

2 Trans-Pacific Partnership Agreement (signed 4 February 2016) [TPP Agreement].

3 David A Gantz 'The TPP and RCEP: Mega-Trade Agreements for the Pacific Rim' (2016) 33 Ariz J Int'l \& Comp L 57 at 59.
} 
thereby placing the regional pact on life support. ${ }^{4} \mathrm{~A}$ year later, however, the 11 remaining TPP partners established the Comprehensive and Progressive Agreement for Trans-Pacific Partnership (CPTPP), which they eventually signed in March 2018. If this modified pact enters into force, it will cover Australia, Brunei Darussalam, Canada, Chile, Japan, Malaysia, Mexico, New Zealand, Peru, Singapore and Vietnam.

The second norm-setting exercise is part of the ongoing negotiations surrounding the Regional Comprehensive Economic Partnership (RCEP). Launched in November 2012, these negotiations built on past trade and non-trade discussions between the Association of Southeast Asian Nations $(A S E A N)^{5}$ and its six major Asian Pacific neighbours (Australia, China, India, Japan, New Zealand and South Korea). Although policymakers, commentators and the media have seldom analysed the RCEP until a few years ago, its 16 negotiating parties 'account for almost half of the world's population, almost 30 per cent of global GDP and over a quarter of world exports'. ${ }^{6}$ Once established, this partnership will cover not only China and India but also two high-income Asian economies (Japan and South Korea) and six other TPP/CPTPP partners (Australia, Brunei Darussalam, Malaysia, New Zealand, Singapore and Vietnam).

Taken together, these two mega-regional norm-setting exercises will have unlimited potential to shape future copyright norms in the Asian Pacific region. For countries that have joined either the CPTPP or the RCEP, legal obligations concerning new protection and enforcement standards will have to be incorporated into domestic law once the applicable agreement enters into force. These standards can be quite burdensome, as they often exceed what is currently required by the Agreement on TradeRelated Aspects of Intellectual Property Rights (TRIPS Agreement) of the World Trade Organization (WTO). ${ }^{7}$ Countries that have joined both the CPTPP and the RCEP will also have to be ready to resolve conflicts between these two agreements, should they arise.

4 Peter K Yu 'Thinking about the Trans-Pacific Partnership (and a Mega-regional Agreement on Life Support)' (2017) 20 SMU Sci \& Tech L Rev 97.

5 The 10 current members are Brunei Darussalam, Cambodia, Indonesia, Laos, Malaysia, Myanmar, the Philippines, Singapore, Thailand and Vietnam. They negotiate as a bloc in the RCEP negotiations.

6 'Regional Comprehensive Economic Partnership' Department of Foreign Affairs and Trade (Australia) dfat.gov.au.

7 Agreement on Trade-Related Aspects of Intellectual Property Rights 1869 UNTS 299 (adopted 15 April 1994, entered into force 1 January 1995) [TRIPS Agreement]. 
Even those countries that remain outside of the CPTPP or the RCEP may end up accepting norms enshrined in either agreement, or both, despite their lack of legal obligation to do so. While some of these countries may introduce new laws or amendments in an effort to harmonise their laws with those of their Asian Pacific neighbours, others, especially the less powerful ones, may face considerable external pressure to accept higher standards stipulated in the new mega-regional agreements.

Moreover, if an Asian Pacific Copyright Code is to be developed a recurring theme of this volume - such development will have to take into account the new copyright norms in the CPTPP and the RCEP, regardless of whether the Code incorporates any of these norms in the end. Any effort to develop such a regional code will also have to anticipate the potential inconsistencies, tensions and conflicts between the CPTPP and the RCEP in the intellectual property area.

In view of these complications and the potentially considerable change in the intellectual property norm-setting landscape in the Asian Pacific region, this chapter closely examines the roles of the (now inoperative) TPP, the CPTPP and the RCEP in shaping future regional copyright norms. It begins by discussing the historical origins of the TPP and the RCEP. It then highlights the similarities and differences between the copyright and intellectual property enforcement provisions in the TPP Agreement and a leaked draft of the RCEP intellectual property chapter. This chapter continues to explore the ramifications for the United States' withdrawal from the TPP and the eventual adoption of the CPTPP. ${ }^{8}$ It concludes by outlining the future of copyright norm-setting in the Asian Pacific region.

8 Donald J Trump 'Withdrawal of the United States from the Trans-Pacific Partnership Negotiations and Agreement' (2017) 82 Fed Reg 8497 [Presidential Memorandum]. 


\section{Historical Origins}

\subsection{TPP}

The origin of the TPP Agreement can be traced back to the early 2000s. The predecessor of this agreement was a quadrilateral agreement known as the Trans-Pacific Strategic Economic Partnership Agreement, more commonly referred to as the 'P4' or 'Pacific 4'. As Meredith Lewis recounted: ${ }^{9}$

[The negotiations were initially] launched by Chile, New Zealand and Singapore at the APEC [Asia-Pacific Economic Cooperation Forum] leaders' summit in 2002. These original negotiations contemplated an agreement amongst the three participating countries, to be known as the Pacific Three Closer Economic Partnership ... . However, Brunei attended a number of rounds as an observer, and ultimately joined the Agreement as a 'founding member'. The Agreement was signed by New Zealand, Chile and Singapore on July 18, 2005 and by Brunei on August 2, 2005, following the conclusion of negotiations in June 2005.

In March 2010, negotiations for an expanded agreement began between Australia, Peru, Vietnam, the United States and the P 4 members. Malaysia, Mexico, Canada and Japan joined the negotiations afterwards.

From its inception, the TPP was negotiated as a highly ambitious and comprehensive trade agreement. As the then United States Trade Representative (USTR), Ronald Kirk, declared at the first round of the TPP negotiations in Melbourne, Australia: ${ }^{10}$

Trans-Pacific Partnership negotiations offer a unique opportunity to shape a high-standard, broad-based regional pact. In line with the President's goal of supporting two million additional American jobs through exports, a robust TPP agreement would expand our exports to one of the world's fastest-growing regions. Our team's aim is to achieve the biggest economic benefits for the American people, and these negotiators will be working to set a new standard for 21 st century trade pacts.

9 Meredith Kolsky Lewis 'Expanding the P-4 Trade Agreement into a Broader Trans-Pacific Partnership: Implications, Risks and Opportunities' (2009) 4 Asian J WTO \& Int'l Health L \& Pol'y 401 at 403-404.

10 Office of the United States Trade Representative 'USTR Begins TPP Talks in Australia' (press release, 15 March 2010). 
After nearly six years of negotiations, an agreement was finally reached in Atlanta in October 2015. ${ }^{11}$ This agreement contains 30 chapters, covering a wide range of issues, such as market access, textiles and apparel, sanitary and phytosanitary measures, investment, financial services, telecommunications, electronic commerce, government procurement, competition, intellectual property, labour, the environment and regulatory standards. The agreement also includes various annexes and side letters regarding tariff commitments, product-specific rules, country-based arrangements and non-conforming measures.

Chapter 18 is devoted entirely to intellectual property matters. ${ }^{12}$ It covers a wide variety of areas, including cooperation, ${ }^{13}$ trademarks, ${ }^{14}$ country names, ${ }^{15}$ geographical indications, ${ }^{16}$ patents and undisclosed test or other data, ${ }^{17}$ industrial designs, ${ }^{18}$ copyright and related rights, ${ }^{19}$ enforcement ${ }^{20}$ and internet service providers. ${ }^{21}$

\subsection{RCEP}

The RCEP negotiations did not start until more than two years after the beginning of the TPP negotiations. Launched in November 2012, the RCEP negotiations were established not solely as a reactive response or a defensive measure. Instead, they built on prior efforts in various fora to facilitate economic integration and cooperation in the Asian Pacific region. These fora include ASEAN+3 (ASEAN, China, Japan and South Korea), ASEAN+6 (ASEAN+3, Australia, India and New Zealand) and APEC.

\footnotetext{
11 Office of the Press Secretary 'Statement by the President on the Trans-Pacific Partnership' (press release, 5 October 2015) [TPP Press Release].

12 TPP Agreement, above n 2, at ch 18.

13 Section B.

14 Section C.

15 Section D.

16 Section E.

17 Section F.

18 Section G.

19 Section $\mathrm{H}$

20 Section I.

21 Section J.
} 
In October 2001, the East Asian Vision Group, which was charged with 'develop[ing] a road map to guide future regional cooperation', ${ }^{22}$ recommended to ASEAN+3 leaders the establishment of the East Asia Free Trade Area. ${ }^{23}$ Although China strongly supported this proposal, Japan and other Asian countries had serious reservations about China's potential dominance in this pact. $^{24}$

Five years later, Japan advanced an alternative proposal concerning the Comprehensive Economic Partnership in East Asia. ${ }^{25}$ Covering not only ASEAN+3 members but also the three remaining ASEAN+6 members (Australia, India and New Zealand), this partnership would dilute China's influence in the regional pact while adding to the mix a major source of natural resources - namely, Australia. ${ }^{26}$

Around that time, APEC members also actively explored regional integration and cooperation efforts. In November 2006, APEC began studying the concept of a Free Trade Area of the Asia-Pacific (FTAAP). ${ }^{27}$ Three years later, APEC leaders pledged to create an agreement to realise this conceptual vision. Since then, APEC leaders have endorsed various declarations laying down the incremental steps needed to realise the FTAAP, including the Pathways to FTAAP and the Beijing Roadmap for APEC's Contribution to the Realization of the FTAAP. ${ }^{28}$

In November 2011, ASEAN, with the support of both China and Japan, proposed to merge the initiatives concerning the East Asia Free Trade Area and the Comprehensive Economic Partnership in East Asia to form the

22 Mark Beeson Institutions of the Asia-Pacific: ASEAN, APEC and Beyond (Routledge, London, 2009) at 78.

23 Shujiro Urata 'Japan's FTA Strategy and a Free Trade Area of the Asia-Pacific' in Charles E Morrison and Eduardo Pedrosa (eds) An APEC Trade Agenda? The Political Economy of a Free Trade Area of the Asia-Pacific (ISEAS Publishing, Singapore, 2007) 99 at 106.

24 Beeson, above n 22, at 88; Shintaro Hamanaka 'Trans-Pacific Partnership versus Regional Comprehensive Economic Partnership: Control of Membership and Agenda Setting' (Asian Development Bank, Working Paper Series on Regional Economic Integration No. 146, December 2014) at 10; Meredith Kolsky Lewis 'Achieving a Free Trade Area of the Asia-Pacific: Does the TPP Present the Most Attractive Path?' in CL Lim, Deborah Kay Elms and Patrick Low (eds) The TransPacific Partnership: A Quest for a Twenty-First Century Trade Agreement (Cambridge University Press, Cambridge, 2012) 223 at 227 (doi.org/10.1017/CBO9781139236775.022).

25 Lewis, above n 24, at 228; Urata, above n 23, at 106-107.

26 Mark Beeson Regionalism and Globalization in East Asia: Politics, Security and Economic Development (Palgrave Macmillan, Basingstoke, 2007) at 224; Urata, above n 23, at 111.

27 Lewis, above n 24, at 223.

28 Asia-Pacific Economic Corporation Forum Pathways to FTAAP (14 November 2010); Asia-Pacific Economic Cooperation Forum The Beijing Roadmap for APEC's Contribution to the Realization of the FTAAP (11 November 2014). 
RCEP. ${ }^{29}$ At the 19th ASEAN Summit in Bali, Indonesia, ASEAN leaders adopted the Framework for Regional Comprehensive Economic Partnership. ${ }^{30}$ Formal negotiations were finally launched in November 2012 at the 21 st ASEAN Summit in Phnom Penh, Cambodia. As ASEAN+6 leaders declared at that time, the RCEP negotiations were established to: ${ }^{31}$

[a]chieve a modern, comprehensive, high-quality and mutually beneficial economic partnership agreement establishing an open trade and investment environment in the region to facilitate the expansion of regional trade and investment and contribute to global economic growth and development; [and]

[b]oost economic growth and equitable economic development, advance economic cooperation and broaden and deepen integration in the region through the RCEP, which will build upon our existing economic linkages.

Although the ASEAN+6 leaders' joint declaration did not specifically mention the TPP, there is no denying that the development of this United States-led partnership greatly accelerated the RCEP negotiations. ${ }^{32}$ The latter negotiations were particularly urgent when two major ASEAN+6 economies, China and India, were intentionally excluded from the TPP. ${ }^{33}$ Also excluded were other key ASEAN+6 members, such as Indonesia, the Philippines, South Korea and Thailand. While some of these countries had been invited to the TPP negotiations but declined to participate, ${ }^{34}$ others were simply ignored.

Undoubtedly, there were both economic and non-economic reasons for not inviting these countries to the TPP negotiations. Yet the outcome was the same: while the excluded countries could still join the partnership once it had been established, they would not be able to shape the standards involved and could only accept the final terms as agreed upon by the

29 Hamanaka, above n 24, at 11; Ganeshan Wignaraja 'The Regional Comprehensive Economic Partnership: An Initial Assessment' in Tang Guoqiang and Peter A Petri (eds) New Directions in Asia-Pacific Economic Integration (East-West Center, Honolulu, 2014) 93 at 94.

30 ASEAN Framework for Regional Comprehensive Economic Partnership (12 June 2012).

31 ASEAN Plus Six Joint Declaration on the Launch of Negotiations for the Regional Comprehensive Economic Partnership (20 November 2012).

32 Du Ming 'Explaining China's Tripartite Strategy toward the Trans-Pacific Partnership Agreement' (2015) 18 J Int'l Econ L 407 at 424; Hamanaka, above n 24, at 13; Michael Wesley 'Who Calls the Tune? Asia Has to Dance to Duelling Trade Agendas' (19 October 2014) The Conversation theconversation.com.

33 Peter K Yu 'TPP and Trans-Pacific Perplexities' (2014) 37 Fordham Int'l LJ 1129 at 1132-1163.

34 Yoo Choonsik 'South Korea Moves Closer to Joining TPP Trade Talks' Reuters (online ed, 29 November 2013); Alan Raybould 'Thailand Says to Join Trans-Pacific Partnership Trade Talks' Reuters (online ed, 18 November 2012). 
original negotiating parties. Such an outcome was highly unattractive, if not unacceptable, to large Asian economies such as China and India. It is therefore unsurprising that these countries have turned their time, attention and energy towards the RCEP to develop regional standards based on their own preferences and experiences. ${ }^{35}$

At the time of writing, ASEAN+6 members have already entered into over 20 rounds of negotiations. Once the RCEP Agreement is completed, the final text is anticipated to cover a wide range of areas, including 'trade in goods, trade in services, investment, economic and technical cooperation, intellectual property, competition [and] dispute settlement ${ }^{3}{ }^{36}$ Beyond these areas, working or sub-working groups have also been established to address rules of origin; customs procedures and trade facilitation; legal and institutional issues; sanitary and phytosanitary measures; standards, technical regulations and conformity assessment procedures; electronic commerce; financial services; and telecommunications. ${ }^{37}$

Given this large number of working and sub-working groups, it remains to be seen whether their establishment will result in the creation of standalone chapters in each specific area. Regardless of how the final agreement is structured, however, that agreement is likely to be as ambitious as the TPP Agreement, which contains 30 different chapters in the final text. In light of this expansive and comprehensive coverage, questions have already been raised about the potential rivalry, compatibility and complementarity between these two mega-regional agreements.

\section{TPP and RCEP Norms}

Although no draft text has thus far been officially released to the public, Knowledge Ecology International made available online a leaked 15 October 2015 draft of the RCEP intellectual property chapter (draft RCEP chapter).$^{38}$ To better understand the copyright norms that are being developed in the Asian Pacific region, it will be instructive to compare this leaked draft with the TPP intellectual property chapter (TPP chapter). ${ }^{39}$

35 Hamanaka, above n 24, at 12-15.

36 ASEAN Plus Six Guiding Principles and Objectives for Negotiating the Regional Comprehensive Economic Partnership (30 August 2012) at preamble [Guiding Principles].

37 'Regional Comprehensive Economic Partnership: News' Department of Foreign Affairs and Trade dfat.gov.au.

38 '2015 Oct 15 version: RCEP IP Chapter' (19 April 2016) Knowledge Ecology International keionline.org [Draft RCEP Chapter].

39 TPP Agreement, above n 2, at ch 18. 
Despite the recent signing of the CPTPP, this comparison continues to focus on the TPP for three reasons. First, the comparison between the TPP chapter and the draft RCEP chapter highlights the significant differences between the two mega-regional norm-setting exercises. These differences not only reflect the varied positions taken by leading players in the Asian Pacific region, but they also underscore the limited divergence between the TPP and RCEP intellectual property norms. Since these two sets of norms have not diverged significantly, it is likely that the CPTPP and RCEP norms will diverge even less. Second, the present comparison paves the way for the discussion of the CPTPP in the next section. That discussion will enable readers to take stock of the select TPP intellectual property provisions that the CPTPP has suspended. It will also allow them to compare the TPP and CPTPP intellectual property norms. Third, this section will become useful should the United States choose to revive the TPP or incorporate its intellectual property norms into future bilateral, regional or plurilateral trade agreements.

Because the scope and coverage of this volume do not allow for a detailed exploration of the large number of intellectual property provisions in the draft RCEP chapter, this section focuses on only the draft sections on copyright and related rights ${ }^{40}$ and enforcement of intellectual property rights. ${ }^{41}$ It is nonetheless worth remembering that other sections or other draft chapters, such as those on investment and electronic commerce, could deeply affect or be relevant to intellectual property protection and enforcement. For example, the TPP investment chapter, which seeks to establish an investor-state dispute settlement mechanism, became highly controversial after Eli Lilly and Philip Morris used similar mechanisms in bilateral or regional trade agreements to address their intellectual property disputes. ${ }^{42}$

\footnotetext{
40 Section 2.

41 Section 9.

42 Eli Lilly and Company v Government of Canada (Final Award) ICSID UNCT/14/2 16 March 2017; Philip Morris Brands Sàrl v Oriental Republic of Uruguay (Award) ICSID ARB/10/7 8 July 2016; Philip Morris Asia Ltd v Commonwealth of Australia (Award on Jurisdiction and Admissibility) UNCITRAL PCA 2012-12 17 December 2015. For these disputes and the use of the investor-state dispute settlement mechanism, see Cynthia M Ho 'Sovereignty under Siege: Corporate Challenges to Domestic Intellectual Property Decisions' (2015) 30 Berkeley Tech LJ 213; Ruth L Okediji 'Is Intellectual Property "Investment"? Eli Lilly $v$ Canada and the International Intellectual Property System' (2014) 35 U Pa J Int'l L 1121; Peter K Yu 'Crossfertilizing ISDS with TRIPS’ (2017) 49 Loy U Chi LJ 321; and Peter K Yu 'The Investment-Related Aspects of Intellectual Property Rights' (2017) 66 Am U L Rev 829.
} 


\subsection{Copyright and Related Rights}

In the area of copyright and related rights, the draft RCEP chapter includes the usual language ${ }^{43}$ found in free trade agreements (FTAs) requiring the accession to the two internet-related treaties of the World Intellectual Property Organization (WIPO) - the WIPO Copyright Treaty and the WIPO Performances and Phonograms Treaty. ${ }^{44}$ Going beyond the terms of the TPP Agreement, the draft chapter ${ }^{45}$ also requires accession to the Beijing Treaty on Audiovisual Performances, ${ }^{46}$ the International Convention for the Protection of Performers, Producers of Phonograms and Broadcasting Organizations (Rome Convention) ${ }^{47}$ and the Marrakesh Treaty to Facilitate Access to Published Works for Persons Who Are Blind, Visually Impaired or Otherwise Print Disabled. ${ }^{48}$

In addition, the draft RCEP chapter includes the usual provisions on technological protection measures and electronic rights management information, ${ }^{49}$ which are both significantly shorter and more flexible than their counterparts in the TPP Agreement. ${ }^{50}$ Targeting online streaming and other new means of digital communication, the draft RCEP chapter also includes provisions addressing the unauthorised communication, or the making available, of a copyright work to the public. ${ }^{51}$ The push for such provisions is understandable considering the increasing volume of copyright infringement litigation concerning works disseminated through streaming or other digital technologies. ${ }^{52}$

43 Draft RCEP Chapter, above n 38, art 1.7.6(g)-(h).

44 WIPO Copyright Treaty 2186 UNTS 121 (adopted 20 December 1996, entered into force 6 March 2002) [WCT]; WIPO Performances and Phonograms Treaty 2186 UNTS 203 (adopted 20 December 1996, entered into force 20 May 2002).

45 Draft RCEP Chapter, above n 38, art 1.7.6(h)-(ibis).

46 Beijing Treaty on Audiovisual Performances (adopted 24 June 2012).

47 International Convention for the Protection of Performers, Producers of Phonograms and Broadcasting Organizations 496 UNTS 43 (adopted 26 October 1961, entered into force 18 May 1964).

48 Marrakesh Treaty to Facilitate Access to Published Works for Persons Who Are Blind, Visually Impaired or Otherwise Print Disabled (adopted 27 June 2013, entered into force 30 September 2016).

49 Draft RCEP Chapter, above n 38, arts 2.3, 2.3bis and 2.3ter.

50 See Susan Corbett 'Free Trade Agreements with the United States, Rulemaking and TPMs: Why Asian Pacific Nations Should Resist Increased Regulation of TPMs in Their Domestic Copyright Laws' in this volume.

51 Draft RCEP Chapter, above n 38, art 2.1.1-2.1.2.

52 Among the leading cases in this area are American Broadcasting Companies v Aereo Inc $134 \mathrm{SCt}$ 2498 (2014) before the United States Supreme Court; ITV Broadcasting Ltdv TVCatchup Ltd (Main Proceedings) [2017] ECLI 144 C-275/15 before the Court of Justice of the European Union; and Maneki TV Saiko Saibansho (18 January 2011) 65 Minshū 121 before the Japanese Supreme Court. 
Among the negotiating parties, there was some effort - notably by Australia - to push for stronger language on copyright limitations and exceptions beyond the mere recitation of the three-step test in the TRIPS Agreement and the WIPO Copyright Treaty. ${ }^{53}$ Article 2.5.3 of the leaked draft states:

Each party shall endeavour to provide an appropriate balance in its copyright and related rights system by providing limitations and exceptions ... for legitimate purposes including education, research, criticism, comment, news reporting, libraries and archives and facilitating access for persons with disability.

The purposes listed in this provision are very similar to those found in the preamble of the United States fair use provision. ${ }^{54}$

Like the TPP chapter, the draft RCEP chapter includes a provision prohibiting government use of infringing computer software. ${ }^{55}$ Unlike the TPP chapter, however, the draft RCEP chapter does not extend the copyright term beyond the life of the author plus 50 years - the minimum required by the Berne Convention for the Protection of Literary and Artistic Works. ${ }^{56}$ The draft RCEP chapter also does not include detailed TPP-like provisions on internet service providers, secondary liability for copyright infringement, and the notice and takedown mechanism (although those provisions could easily have been negotiated as part of the yet-to-bedisclosed electronic commerce chapter, if that chapter indeed exists).

To the disappointment of consumer advocates and civil society organisations, South Korea proposed language that would require countries to 'take effective measures to curtail repetitive infringement of copyright and related rights on the Internet or other digital network. ${ }^{57}$ In addition, Japan called for the disclosure of information concerning the accounts of allegedly infringing internet subscribers. ${ }^{58}$ It further advanced a footnote supporting 'a regime providing for limitations on the liability of, or on the remedies available against, online service providers while preserving the legitimate interests of [the] right holder'. ${ }^{59}$

53 TRIPS Agreement, above n 7, art 13; WCT, above n 44, art 10(1).

5417 USC \$ 107.

55 Draft RCEP Chapter, above n 38, art 4.2.

56 Berne Convention for the Protection of Literary and Artistic Works 1161 UNTS 31 (adopted

9 September 1886, entered into force 5 December 1887, revised at Paris 24 July 1971) art 7(1).

57 Draft RCEP Chapter, above n 38, art 9quinquies.3.

58 Article 9quinquies.4.

59 Article 9quinquies.2, n 43. 
Even more alarming to many developing countries, the draft RCEP chapter offers stronger and more expansive protection to broadcasters than the TPP chapter, covering such issues as the unauthorised retransmission of television signals over the internet. ${ }^{60}$ As Jeremy Malcolm commented: ${ }^{61}$

Based on the current text proposals, [the] RCEP may actually impose more stringent protections for broadcasters than the TPP does. The TPP allows authors, performers and producers to control the broadcast of their work, but it does not bestow any independent powers over those works upon broadcasters. [The] RCEP, in contrast, could create such new powers; potentially providing broadcasters with a 50 year monopoly over the retransmission of broadcast signals, including retransmission of those signals over the Internet.

\subsection{Intellectual Property Enforcement}

With respect to intellectual property enforcement, the draft RCEP chapter includes the usual provisions concerning civil, criminal and administrative procedures and remedies, as well as provisional and border measures. Although a considerable portion of the draft language in the enforcement section merely reaffirms the existing rights and obligations under the TRIPS Agreement, the proposed language increases the obligations concerning the seizure and destruction of allegedly infringing goods, including the grant of authority to take ex officio action ${ }^{62}$ and to seize or destroy the materials or implements used to create infringing goods. ${ }^{63}$ The draft chapter also seeks to empower judicial authorities to determine damages for intellectual property infringement based on lost profits, the market price or the suggested retail price. ${ }^{64}$

Like the TPP chapter, the draft RCEP chapter calls for criminal procedures and penalties for unauthorised camcording in cinemas. ${ }^{65}$ Unlike the TPP, however, the draft RCEP chapter does not have extensive provisions on criminal procedures and penalties. These provisions do not apply to

60 Article 2.6.

61 Jeremy Malcolm 'RCEP: The Other Closed-Door Agreement to Compromise Users' Rights'

(20 April 2016) Electronic Frontier Foundation www.eff.org.

62 Draft RCEP Chapter, above n 38, art 9 ter.5.

63 Articles 9bis.5, 9bis.6, 9 bis. 10 and 9quater.6.

64 Article 9bis.2(i).

65 Article 9quinquies.5. 
either trade secret infringement or the circumvention of technological protection measures. The draft provisions on border measures are also less detailed and less invasive. ${ }^{66}$

At the time when the leaked draft was being negotiated, the RCEP negotiating parties strongly disagreed on the appropriate standards concerning criminal liability for aiding and abetting, ${ }^{67}$ the award of attorneys' fees ${ }^{68}$ and obligations relating to intellectual property enforcement in the digital environment. ${ }^{69}$ Facing strong opposition from its negotiating partners, South Korea remained the lone party calling for the provision of pre-established damages. ${ }^{70}$

In sum, the draft RCEP chapter, like any other treaty in the middle of the negotiation process, includes a wide array of bracketed texts. While some draft provisions are stronger than, or similar to, what is found in the TPP Agreement, other language is much weaker. The draft text also includes language that cannot be found in the TPP Agreement or other TRIPS-plus FTAs. Given that 'nothing is agreed until everything is agreed $^{71}$ - a favourite aphorism of treaty negotiators and other government officials - it remains to be seen what the final RCEP intellectual property chapter will look like.

\section{United States' TPP Withdrawal and the Adoption of the CPTPP}

The previous section has shown that both the TPP chapter and the draft RCEP chapter have called for higher protection and enforcement standards that go beyond what is required by the TRIPS Agreement. While differences still exist between the two chapters, it will not be farfetched to assume that the copyright norms in the Asian Pacific region will be greatly strengthened once either agreement, if not both, enters

66 Article 9ter.

67 Article 9quater.4.

68 Article 9bis.4.

69 Article 9quinquies.

70 Article 9 bis.3.

71 Henrique C Moraes 'Dealing with Forum Shopping: Some Lessons from the Negotiation on SECURE at the World Customs Organization' in Li Xuan and Carlos Correa (eds) Intellectual Property Enforcement: International Perspectives (Edward Elgar Publishing, Cheltenham, 2009) 159 at 176. 
into force. Nevertheless, this seemingly predictable norm-setting picture has been complicated by the United States' withdrawal from the TPP in January $2017 .^{72}$

Although the Obama Administration described this mega-regional agreement as a 'cardinal priority and a cornerstone of [its] Pivot to Asia', ${ }^{73}$ its successor made an about turn within a year of signing the TPP Agreement. On the first day of his first full week in office, President Trump signed a memorandum directing the USTR to 'withdraw the United States as a signatory to the [TPP and] ... from the TPP negotiations' ${ }^{74}$ As the document stated, 'it is the intention of [the new] Administration to deal directly with individual countries on a one-on-one (or bilateral) basis in negotiating future trade deals'. Not only did the Trump Administration abandon the TPP Agreement after six years of exhaustive negotiations, but it also shifted the policy emphasis away from regional and plurilateral trade agreements. ${ }^{75}$

Given the United States' new policy position, one cannot help but wonder what the future will hold for the TPP Agreement and its high TRIPS-plus intellectual property norms. Will this mega-regional agreement meet the same fate as the widely criticised Anti-Counterfeiting Trade Agreement (ACTA) ${ }^{76}$ which was signed by most negotiating parties but failed to attain the requisite number of ratifications? ${ }^{77}$ Will the Trump Administration eventually change its course? Or will other TPP partners manage to salvage the agreement even without the United States' participation?

Shortly after the announcement of the United States' withdrawal, Australia, Japan, Singapore and New Zealand explored ways to resuscitate the TPP Agreement. ${ }^{78}$ At a May 2017 APEC meeting in Hanoi, Vietnam, these countries, along with other remaining TPP partners, reaffirmed their commitment to establishing the regional partnership and agreed to explore the development of a process to move the pact forward even

72 Presidential Memorandum, above $\mathrm{n} 8$.

73 Kurt M Campbell The Pivot: The Future of American Statecraft in Asia (Twelve, New York, 2016) at 268 .

74 Presidential Memorandum, above $\mathrm{n} 8$.

75 Peter K Yu 'Trump's Trade Policy Is More Predictable and Less Isolationist than Critics Think'

(3 February 2017) MarketWatch www.marketwatch.com.

76 Anti-Counterfeiting Trade Agreement 50 ILM 243 (adopted 15 April 2011) [ACTA].

77 Despite its adoption in April 2011, the ACTA has thus far been ratified by only one country Japan, the country of depositary.

78 Bhavan Jaipragas 'Can the Trans-Pacific Partnership Be Salvaged? Forget Trump - Malaysia, Australia, New Zealand Think So' South China Morning Post (online ed, 24 January 2017). 
without the United States' participation..$^{79}$ These proactive remedial efforts made good sense considering that Japan and New Zealand had already ratified the agreement.

A few months later, the 11 remaining TPP partners 'agreed on the core elements' of the CPTPP, opting to retain the majority of the original pact while suspending those provisions that had been pushed by United States negotiators but were of no interest, or of very limited interest, to the remaining partners. ${ }^{80}$ On 23 January 2018, exactly a year after President Trump signed his controversial presidential memorandum, the CPTPP negotiations concluded in Tokyo, Japan. The agreement was subsequently signed in Santiago, Chile, on 8 March.

Although art 1 of the CPTPP incorporates by reference all 30 chapters of the TPP Agreement, ${ }^{81}$ including the intellectual property chapter, art 2 suspends the following provisions: ${ }^{82}$

- $\quad$ art 18.63 (Term of Protection for Copyright and Related Rights);

- art 18.68 (Technological Protection Measures);

- art 18.69 (Rights Management Information);

- art 18.79 (Protection of Encrypted Program-Carrying Satellite and Cable Signals); and

- art 18.82 (Legal Remedies and Safe Harbours).

For comparative purposes, the above list includes only those provisions that relate to copyright and related rights and enforcement of intellectual property rights. It is worth noting that the CPTPP has also suspended many provisions in the areas of patents and undisclosed information.

The suspension of all of these provisions has greatly impacted on the future of intellectual property norm-setting in the Asian Pacific region. Not only has such suspension minimised the differences between the TPP/CPTPP and RCEP intellectual property norms, it has also caused the draft RCEP chapter to offer stronger protection than the CPTPP. Notwithstanding these complications, a proper comparison between the TPP/CPTPP and

79 'Pacific Ministers Commit to Move Ahead with Pact without US' US News \& World Report (online ed, 21 May 2017).

80 'Trans-Pacific Partnership Ministerial Statement' (press release, 11 November 2017) at para 3.

81 Comprehensive and Progressive Agreement for Trans-Pacific Partnership (signed 8 March 2018) art 1 [CPTPP].

82 Annex, art 7(g)-(k). 
RCEP intellectual property norms will have to take into consideration not only the recent suspension of select TPP provisions, but also the time that has elapsed since the leaked RCEP draft chapter.

The draft RCEP chapter was leaked more than two years ago. Most certainly, the negotiations of that chapter have already advanced beyond what the October 2015 draft has revealed. Moreover, the TPP/CPTPP and the RCEP were established as two rivalrous, though potentially complementary, norm-setting exercises. It will therefore be no surprise if the RCEP has been negotiated in the shadow of the TPP negotiations and the post-TPP developments. Now that the CPTPP offers much weaker protection than the TPP, many RCEP negotiating partners will understandably demand lower standards that correspond to the CPTPP.

Nevertheless, while the CPTPP has played an important and fast-growing role in intellectual property norm-setting in the Asian Pacific region, we should not ignore the lingering impact of the TPP. As I noted in an earlier article, regardless of whether the TPP is dead or alive, it may exert four types of influence that will deeply affect the future of intellectual property norm-setting in the Asian Pacific region. ${ }^{83}$

To begin with, the various chapters in the TPP Agreement, including its intellectual property chapter, may continue to provide the much-needed templates for drafting future bilateral, regional and plurilateral trade agreements. Thus far, the United States has relied heavily on templates to maximise effectiveness and efficiency in trade negotiations. ${ }^{84}$ As policies change and new issues arise, these templates will be updated. Indeed, many terms in the earlier FTAs developed by the United States have already found their way to later agreements. In the intellectual property arena, for instance, ACTA and the TPP Agreement have all incorporated terms from these agreements, most notably the Korea - United States Free Trade Agreement. ${ }^{85}$

83 Yu, above $\mathrm{n}$ 4, at 101-110.

84 Peter Drahos 'BITs and BIPs: Bilateralism in Intellectual Property' (2001) 4 J World Intell Prop 791 at 794; Susy Frankel 'Challenging TRIPS-Plus Agreements: The Potential Utility of NonViolation Disputes' (2009) 12 J Int'l Econ L 1023 at 1025; Peter K Yu 'Sinic Trade Agreements' (2011) 44 UC Davis L Rev 953 at 1011-1013.

85 Peter K Yu 'Trade Agreement Cats and the Digital Technology Mouse' in Bryan Mercurio and Ni Kuei-Jung (eds) Science and Technology in International Economic Law: Balancing Competing Interests (Routledge, London, 2014) 185 at 196. 
Even more disturbing, South Korea injected the terms of its FTA with the United States into the RCEP negotiations, despite the fact that the United States is not a party to those negotiations. ${ }^{86}$ As Jeremy Malcolm lamented: ${ }^{87}$

Far from setting up a positive alternative to the TPP, South Korea is channeling the USTR at its worst here - what on earth are they thinking? The answer may be that, having been pushed into accepting unfavorably strict copyright, patent, and trademark rules in the process of negotiating its 2012 free trade agreement with the United States, Korea considers that it would be at a disadvantage if other countries were not subject to the same restrictions.

The second type of influence relates to the potential development of new international intellectual property norms that will incorporate the TPP Agreement by reference. A widely cited example of such development is the TRIPS Agreement's incorporation of the Washington Treaty on Intellectual Property in Respect of Integrated Circuits. Although the latter treaty has never entered into force, art 35 of the TRIPS Agreement explicitly incorporates its obligations as follows: ${ }^{88}$

Members agree to provide protection to the layout-designs (topographies) of integrated circuits ... in accordance with Articles 2 through 7 (other than paragraph 3 of Article 6), Article 12 and paragraph 3 of Article 16 of the Treaty on Intellectual Property in Respect of Integrated Circuits .... .

The third type of influence concerns the potential use of the terms of the TPP Agreement to determine whether a country has adequately protected intellectual property rights. Of great notoriety regarding this type of determination is the USTR's Special 301 process. ${ }^{89}$ As the United States Trade Act stipulates, the USTR can take Special 301 actions against

86 Peter K Yu 'The RCEP and Trans-Pacific Intellectual Property Norms' (2017) 50 Vand J Transnat'l L 673 at $700-701$.

87 Jeremy Malcolm 'Meet RCEP, a Trade Agreement in Asia That's Even Worse than TPP or ACTA' (4 June 2015) Electronic Frontier Foundation www.eff.org.

88 TRIPS Agreement, above $\mathrm{n} 7$, art 35 .

8919 USC $\$ \$ 2411-2420$. On this process, see Jagdish Bhagwati and Hugh T Patrick (eds) Aggressive Unilateralism: America's 301 Trade Policy and the World Trading System (University of Michigan Press, Ann Arbor, 1990); Joe Karaganis and Sean Flynn 'Networked Governance and the USTR' in Joe Karaganis (ed) Media Piracy in Emerging Goods (Social Science Research Council, New York, 2011) 75 at 75-98; Paul C B Liu 'U.S. Industry's Influence on Intellectual Property Negotiations and Special 301 Actions' (1994) 13 UCLA Pac Basin LJ 87. 
countries that have failed to provide 'adequate and effective protection of intellectual property rights notwithstanding the fact that [they] may be in compliance with the specific obligations of the [TRIPS] Agreement ${ }^{9}{ }^{0}$

For instance, the USTR has repeatedly put Canada on the Special 301 Watch List, citing the country's failure to ratify the WIPO Internet Treaties, among other reasons. ${ }^{91}$ Likewise, before China acceded to those treaties, the USTR stated in the 2005 National Trade Estimate Report on Foreign Trade Barriers that the United States consider[ed] the WIPO treaties to reflect many key international norms for providing copyright protection over the Internet'. ${ }^{92}$ The report further stated that 'China's accession to the WIPO treaties [was] an increasingly important priority for the United States'. ${ }^{93}$

The final type of influence pertains to the potential misguidance provided by technical assistance experts. Given the politically driven circumstances surrounding the United States' withdrawal from the TPP, these experts may continue to treat the intellectual property provisions in the TPP Agreement as the world's best practices - or, worse, the gold standard for intellectual property protection and enforcement. ${ }^{94}$ Oftentimes, these so-called 'best practices' are introduced without regard to a particular country's local needs, interests, conditions or priorities. For developing countries, overemphasis on the high TPP intellectual property standards as international benchmarks may ultimately undermine the countries' individual abilities to take advantage of the traditional limitations, safeguards and flexibilities provided in the TRIPS Agreement or other WIPO-administered international intellectual property agreements. ${ }^{95}$

In sum, although the TPP Agreement will not have any legal effect like the CPTPP, nor will it have as big an impact as it would have had upon taking effect, it may continue to exert considerable influence on intellectual property norm-setting in the Asian Pacific region. Thus, as important as it is to appreciate the growing role of the CPTPP and the ramifications

9019 USC $\$ 2411$ (d)(3)(B)(i)(II) (emphasis added).

91 Office of the US Trade Representative 2010 Special 301 Report (Washington, 2010) at 25.

92 Office of the US Trade Representative 2005 National Trade Estimate Report on Foreign Trade Barriers (Washington, 2005) at 96.

93 Ibid.

94 Kimberlee Weatherall 'Intellectual Property in the TPP: Not "the New TRIPS"' (2016) 17 Melb J Int'l L 257 at 276.

95 Peter K Yu 'The International Enclosure Movement' (2007) 82 Ind LJ 827 at 869-870. 
for the suspended TPP intellectual property provisions, policymakers and commentators in the region should not overlook the lingering influence of the TPP.

\section{Future of Copyright Norm-Setting}

Although the ratification of the TPP sparked considerable debate, the United States' subsequent withdrawal from the regional pact has generated a new line of inquiry concerning the future of intellectual property normsetting in the Asian Pacific region. Will the United States finally lose ground to China in its effort to shape future regional intellectual property norms? ${ }^{96}$ Will the developments surrounding the TPP and the CPTPP accelerate or retard the RCEP negotiations? Will the RCEP negotiating parties eventually reject the inclusion of an intellectual property chapter in their regional pact in light of the complications surrounding the TPP and the CPTPP?

To address this line of inquiry, this section focuses on three specific questions. First, will the United States' withdrawal from the TPP and the recent adoption of the CPTPP lead to the omission of an intellectual property chapter in the RCEP Agreement? Second, if such a chapter indeed exists, will it contain high protection and enforcement standards? Third, will the ultimate standards adopted in the RCEP Agreement conflict with those stipulated in the CPTPP or other FTAs developed by the United States, including a revived or modified TPP Agreement?

\subsection{An Intellectual Property Chapter?}

The first question concerning whether the RCEP Agreement will contain an intellectual property chapter is easy to answer. Although it is still possible for the RCEP negotiating parties to reject the inclusion of such a chapter, especially in light of the wide variation in intellectual property protection

96 Giovanni Di Lieto 'If the TPP Dies, Australia Has Other Game Changing Trade Options' (4 September 2016) The Conversation theconversation.com; Nicholas Ross Smith 'China Will Be the Winner if US Backs Out of the TPP' (1 August 2016) The Conversation theconversation.com. 
and enforcement across the Asian Pacific region, ${ }^{97}$ past negotiations and ongoing developments have indicated a strong likelihood for this chapter to exist.

There are at least three strands of evidence to support such an existence. First, when ASEAN+6 members adopted the Guiding Principles and Objectives for Negotiating the Regional Comprehensive Economic Partnership in August 2012, they agreed to include an intellectual property text in the RCEP Agreement. ${ }^{98}$ After the establishment of the Working Group on Intellectual Property at the third round of the RCEP negotiations in January 2014, that group has also worked actively to develop the draft text of the intellectual property chapter. ${ }^{99}$ Absent any catastrophic developments in the RCEP negotiations, the time and effort invested in this working group is just too substantial for the chapter to be abandoned at this late stage.

Second, given the importance of intellectual property industries to countries such as Australia, Japan, New Zealand and South Korea, it is very unlikely that these countries will be content with a regional trade and investment agreement that does not contain an intellectual property chapter. If these countries threaten to pull out of the RCEP negotiations, the key question for the remaining ASEAN +6 members will no longer be about whether the agreement should omit an intellectual property chapter, but whether such omission is so important to them that they would rather lose the entire regional pact or the participation of key neighbours in this pact than include the chapter.

Third, apart from the developed country members of ASEAN+6, China, India and other emerging countries in the region - or what I have called 'middle intellectual property powers' ${ }^{100}$ - have begun to appreciate the strategic benefits of stronger intellectual property protection and enforcement. Although these countries have yet to embrace the very high protection and enforcement standards found in the European Union, Japan or the United States, they now welcome standards that are higher

97 Peter K Yu 'Clusters and Links in Asian Intellectual Property Law and Policy' in Christoph Antons (ed) Routledge Handbook of Asian Law (Routledge, Milton Park, 2017) 147 at 148; Peter K Yu 'Intellectual Property and Asian Values' (2012) 16 Marq Intell Prop L Rev 329 at 339-370.

98 Guiding Principles, above n 36, $\mathrm{s}$.

99 'Regional Comprehensive Economic Partnership: News', above n 37.

100 Peter K Yu 'The Middle Intellectual Property Powers' in Randall Peerenboom and Tom Ginsburg (eds) Law and Development in Middle-Income Countries: Avoiding the Middle-Income Trap (Cambridge University Press, New York, 2014) 84 at 84 . 
than those currently available in the Asian Pacific region. These countries are therefore unlikely to block the inclusion of an intellectual property chapter in the RCEP Agreement.

\subsection{High Intellectual Property Standards?}

The second question concerning whether the RCEP intellectual property chapter will contain high protection and enforcement standards is much harder to answer. To begin with, it is difficult to predict the actual content of any unfinished and fast-evolving chapter. That the RCEP Agreement will provide for special and differential treatment ${ }^{101}$ - a key distinction from the TPP or the CPTPP - has made such prediction particularly difficult. After all, the more special accommodation the agreement will provide to developing countries, the more eager their developed counterparts are to demand high overall standards.

At first glance, lower protection and enforcement standards will provide greater benefits to countries in the Asian Pacific region. Because many of these countries are still developing countries, they will be better off declining the adoption of high intellectual property standards, which tend to ignore their local needs, national interests, technological capabilities, institutional capacities and public health conditions. ${ }^{102}$ At the time of writing, there remain significant regional variations in economic condition, imitative or innovative capacity, research and development productivity and availability of human capital. An innovative model that works well in the developed world is therefore unlikely to work well in the developing world. ${ }^{103}$ Not only may the unquestioned adoption of high intellectual property standards from abroad fail to result in greater innovative efforts,

101 Shujiro Urata 'A Stages Approach to Regional Economic Integration in Asia Pacific: The RCEP, TPP, and FTAAP' in Tang Guoqiang and Peter A Petri (eds) New Directions in Asia-Pacific Economic Integration (East-West Center, Honolulu, 2014) 119 at 127.

$102 \mathrm{Yu}$, above n 95, at 866-870.

103 Claudio R Frischtak 'Harmonization versus Differentiation in Intellectual Property Rights Regime' in Mitchel B Wallerstein, Mary Ellen Mogee and Roberta A Schoen Global Dimensions of Intellectual Property Rights in Science and Technology (National Academy Press, Washington, 1993) 89 at 93-97; David Silverstein 'Intellectual Property Rights, Trading Patterns and Practices, Wealth Distribution, Development and Standards of Living: A North-South Perspective on Patent Law Harmonization' in George R Stewart, Myra J Tawfik and Maureen Irish (eds) International Trade and Intellectual Property: The Search for a Balanced System (Westview Press, Boulder, 1994) 155 at 156; Yu, above n 95, at 889 . 
industrial progress and technology transfers, such adoption may drain away the resources needed for dealing with the socioeconomic and public health problems created by the new legislation.

Even worse, the introduction of legal reforms based on foreign intellectual property systems may exacerbate the dire economic plight of many developing countries, as these new laws would enable foreign rights holders in developed and emerging countries to crush local industries through lawsuits or litigation threats. ${ }^{104}$ Even if these new laws could be beneficial in the long run, many of these countries might not have the wealth, infrastructure and technological base to take advantage of the opportunities created by the system in the short run. ${ }^{105}$ For countries with urgent public policy needs or a dying population due to inaccessibility to essential medicines, the realisation of the hope for a brighter long-term future seems far away, if not unrealistic. If protection were strengthened beyond the point of an appropriate balance, the present population would undoubtedly suffer greatly.

As if these challenges were not difficult enough, greater harmonisation of intellectual property standards, while potentially beneficial, can take away valuable opportunities for experimentation with new regulatory and economic policies. ${ }^{106}$ The lack of diversified standards can also reduce competition among jurisdictions while preventing each jurisdiction from deciding for itself what rules and systems it wants to adopt, thereby rendering the lawmaking process less accountable to the local populations. ${ }^{107}$ In the digital age, when laws are hastily introduced and often without convincing empirical evidence, greater experimentation and competition are badly needed. ${ }^{108}$

Notwithstanding the many potential problems and challenges brought about by transplanting intellectual property standards from abroad, the technological rise of China, India and other emerging countries in the Asian Pacific region in the past decade has called for a pause to rethink appropriate intellectual property norm-setting strategies. During the

104 Ellen 't Hoen 'TRIPS, Pharmaceutical Patents, and Access to Essential Medicines: A Long Way from Seattle to Doha' (2002) 3 Chi J Int'l L 27 at 30-31.

105 Keith E Maskus Intellectual Property Rights in the Global Economy (Institute for International Economics, Washington, 2000) at 237.

106 John F Duffy 'Harmony and Diversity in Global Patent Law' (2002) 17 Berkeley Tech LJ 685 at $707-708$.

107 At 706-707.

108 Peter K Yu 'Anticircumvention and Anti-Anticircumvention' (2006) 84 Denv U L Rev 13 at $40-58$. 
TRIPS negotiations, developing countries were repeatedly told that the TRIPS Agreement, along with other commitments in the WTO, would provide the painful medicine needed to boost economic development. ${ }^{109}$ Although it is easy to dismiss the sales pitch of TRIPS advocates and supporters, it is much harder to evaluate whether China, India and the now-emerging countries in the Asian Pacific region have in fact benefited from the many economic reforms pushed on them by the WTO Agreement.

Consider China, for example. Many policymakers and commentators have now taken the view that China would not have been as economically developed and as technologically proficient as it is today had it not embraced the reforms required by WTO accession. ${ }^{110}$ Moreover, as China moved from the stage of transplanting foreign laws to the stage of developing indigenous standards, ${ }^{111}$ it has skilfully deployed 'selective adaptation' strategies ${ }^{112}$ to ensure the incorporation of only beneficial features from the outside without also transplanting the harmful and unsuitable elements. ${ }^{113}$

In sum, even though one could continue to debate how much China, India and other emerging countries have benefited from TRIPS-induced intellectual property reforms, it is much harder to deny the contributions the TRIPS Agreement has provided to the economic development and technological proficiency in these countries. Thus, as much as policymakers and commentators are eager to criticise the deleterious effects of TRIPSplus bilateral, regional and plurilateral agreements, such as the TPP, the CPTPP and the RCEP, they cannot lose sight of the agreements' potential positive benefits.

\footnotetext{
109 Daniel J Gervais 'The TRIPS Agreement and the Doha Round: History and Impact on Economic Development' in Peter K Yu (ed) Intellectual Property and Information Wealth: Issues and Practices in the Digital Age (Praeger Publishers, Westport, 2007) vol 4, 23 at 43.

110 Campbell, above n 73, at 195; Peter K Yu 'The Rise and Decline of the Intellectual Property Powers' (2012) 34 Campbell L Rev 525 at 550-551; Gordon G Chang 'TPP vs. RCEP: America and China Battle for Control of Pacific Trade' National Interest (online ed, 6 October 2015).

111 Guo He 'Patents' in Rohan Kariyawasam (ed) Chinese Intellectual Property and Technology Laws (Edward Elgar Publishing, Cheltenham, 2011) 25 at 28; Peter K Yu 'Building the Ladder: Three Decades of Development of the Chinese Patent System' (2013) 5 WIPO J 1 at 3-13.

112 Pitman B Potter 'China and the International Legal System: Challenges of Participation' in Donald C Clarke (ed) China's Legal System: New Developments, New Challenges (Cambridge University Press, Cambridge, 2008) 145 at 147-148; Wu Handong 'One Hundred Years of Progress: The Development of the Intellectual Property System in China' (2009) 1 WIPO J 117 at 118-119. 113 Peter K Yu 'The Transplant and Transformation of Intellectual Property Laws in China' in Nari Lee, Niklas Bruun and Li Mingde (eds) Governance of Intellectual Property Rights in China and Europe (Edward Elgar Publishing, Cheltenham, 2016) 20 at 26.
} 


\subsection{A Battle between the TPP, the CPTPP and the RCEP?}

The last question concerning the conflicts between the TPP and the RCEP sometimes arises in view of the different leaderships involved. The adoption of the CPTPP has further complicated this question. While the TPP and the CPTPP evidence the leadership of the United States and Japan, respectively, many policymakers and commentators consider the RCEP a China-led mega-regional agreement. In light of such different leadership, it is logical to ask whether the TPP, the CPTPP and the RCEP would create conflicting obligations - or precipitate what I have described as the 'battle of the FTAs'. ${ }^{114}$

These conflicting obligations will be problematic for not only developing countries in the Asian Pacific region but also their developed counterparts. Juggling different standards within the same region will be costly, inefficient and highly challenging. Even more importantly, the conflicts between the TPP/CPTPP and the RCEP will make Asia 'a vital battleground in setting the rules of the global economic order'. ${ }^{115}$ As President Barack Obama declared after the conclusion of the TPP negotiations in Atlanta in October 2015:116

When more than 95 percent of our potential customers live outside our borders, we can't let countries like China write the rules of the global economy. We should write those rules, opening new markets to American products while setting high standards for protecting workers and preserving our environment.

Interestingly, this proverbial battle between the TPP and the RCEP did not materialise before the United States withdrew from the TPP. Although the standards in the draft RCEP chapter still differ from their counterparts in the TPP Agreement, they were closer to each other than many anticipated. With the adoption of the CPTPP and the suspension of a number of TPP intellectual property provisions, the TPP/CPTPP and RCEP standards have become even closer. Thus, one could make a strong case that the two mega-regional norm-setting exercises, whether

114 Yu, above n 84, at 1018-1027.

115 Campbell, above n 73, at 267.

116 TPP Press Release, above n 11. 
before or after the adoption of the CPTPP, reflect a growing convergence of regional intellectual property standards, similar to that induced by the TRIPS Agreement. ${ }^{17}$

There are at least five reasons why the TPP/CPTPP and RCEP negotiations have not led to significant conflicting obligations. First, seven of the 16 RCEP negotiating parties - or, to be more precise, three and a half of the seven parties (Australia, Japan, New Zealand and close to half of ASEAN) - are TPP/CPTPP partners. As a result, they will have strong incentives to ensure that they can join the RCEP without violating the commitments made under the TPP Agreement or the CPTPP. ${ }^{118}$ If conflicts do arise, they are unlikely to be blatant, but will instead be more subtle and highly specific.

Second, as noted earlier, China, India and other emerging countries within ASEAN+6 have begun to realise the growing benefits of increased intellectual property protection and enforcement. As a result, they no longer mount as much resistance as they did to those high intellectual property standards that have already been widely adopted in the developed world. In fact, some leaders of these countries may welcome new RCEP standards, as these standards will provide the much-needed external push to accelerate domestic intellectual property reforms. ${ }^{119}$

Third, although China has wielded considerable influence in the RCEP negotiations, it has thus far kept a rather low profile. This negotiation posture is consistent with the approach China has taken in other international trade and intellectual property negotiations. ${ }^{120}$ In regard to the draft RCEP chapter, for instance, China did not even advance a proposal. As revealed by Knowledge Ecology International, the draft proposals came from other negotiating parties - namely, ASEAN, India,

117 Yu 'Clusters and Links', above n 97, at 150-151.

118 Meredith Kolsky Lewis 'The TPP and the RCEP (ASEAN+6) as Potential Paths toward Deeper Asian Economic Integration' (2013) 8 Asian J WTO \& Int'l Health L and Pol'y 359 at 369-370.

119 Peter K Yu 'Intellectual Property, Economic Development, and the China Puzzle' in Daniel J Gervais (ed) Intellectual Property, Trade and Development: Strategies to Optimize Economic Development in a TRIPS Plus Era (1st ed, Oxford University Press, Oxford, 2007) 173 at 192.

120 Henry S Gao 'China's Participation in the WTO: A Lawyer's Perspective' (2007) 11 Singapore Yearbook of International L 41 at 69; Peter K Yu 'The Middle Kingdom and the Intellectual Property World' (2011) 13 Or Rev of Int'l L 209 at 229-237. 
Japan and South Korea. ${ }^{121}$ The only area in which China has taken a more assertive position concerns the disclosure in patent applications of the source of origin of genetic resources used in the inventions, ${ }^{122}$ a requirement that already exists in art 26 of the Chinese Patent Law. ${ }^{123}$

Fourth, if the RCEP is to successfully compete with the TPP/CPTPP as a viable alternative for setting trade norms in the Asian Pacific region, it will need to provide effective standards in the intellectual property area. Otherwise, it will lose the support of those economies that are driven heavily by intellectual property and technology industries. Although the United States' withdrawal from the TPP has greatly reduced the competition the RCEP faces, the adoption of the CPTPP has revived such competition while retaining the possibility for the United States to resuscitate the TPP. In view of such competition, the RCEP will need to provide standards that are high enough to entice existing and future TPP/CPTPP partners to embrace the partnership as a dominant forum for setting regional intellectual property norms. Without such participation, a new regional pact could easily emerge to displace the RCEP even if the CPTPP is not eventually ratified.

Finally, ASEAN+6 leaders anticipate the coexistence of the TPP/ CPTPP and the RCEP, as revealed in the key documents relating to the development of the FTAAP. ${ }^{124}$ Adopted in November 2010, the Pathways to FTAAP registered the ASEAN+6 leaders' belief that 'an FTAAP should be pursued ... by developing and building on ongoing regional undertakings, such as ASEAN+3, ASEAN+6, and the TransPacific Partnership, among others.' ${ }^{25}$ The Beijing Roadmap for APEC's Contribution to the Realization of the FTAAP, which was released four years later, further stated that ' $[\mathrm{t}]$ he FTAAP should aim to minimize any negative effects resulting from the proliferation of regional and bilateral [trade agreements]'. ${ }^{126}$

121 '2014 Oct 3 Version: Korea Proposal for RECP IP Chapter (Regional Comprehensive Economic Partnership)' (3 June 2015) Knowledge Ecology International www.keionline.org; '2014 Oct 3 Version: Regional Comprehensive Economic Partnership, Japan IPR Proposals, RCEP' (9 February 2015) Knowledge Ecology International www.keionline.org; '2014 Oct 10: ASEAN Proposals for RECP IP Chapter, Also India' (8 June 2015) Knowledge Ecology International www.keionline.org; Yu, above $n$ 86, at 683-684.

122 Draft RCEP Chapter, above n 38, art 7.1.

123 Patent Law of the People's Republic of China (promulgated 12 March 1984, amended 27 December 2008, effective 1 October 2009) art 26.

124 Urata, above n 101, at 128-129.

125 Asia-Pacific Economic Corporation Forum Pathways to FTAAP (14 November 2010).

126 Asia-Pacific Economic Cooperation Forum The Beijing Roadmap for APEC's Contribution to the Realization of the FTAAP (11 November 2014). 
Indeed, many policymakers and commentators believe the two megaregional agreements will eventually merge. ${ }^{127}$ As Kurt Campbell observed, '[f] or many in Asia, both the TPP and the RCEP are way stations on the path to the ultimate destination'. ${ }^{128}$ The anticipated merger is easy to understand considering that no ASEAN member - or, for that matter, Australia, New Zealand or any other RCEP negotiating party - wants to pick between Beijing and Washington in developing their trade relations, despite their ongoing concern about China's growing economic and military strength. ${ }^{129}$ Many ASEAN+6 members and their industries also cannot afford to have two expansive yet conflicting sets of regional trade and trade-related standards. ${ }^{130}$ At some point, they will have to decide whether they want to focus on one or the other.

\section{Conclusion}

Regardless of the intellectual property standards ultimately included in the RCEP Agreement, that agreement, if established, will have serious ramifications for future intellectual property norm-setting in the Asian Pacific region. These ramifications will be similar to those concerning the establishment of the TPP or the CPTPP. To some extent, the megaregional norm-setting exercises surrounding both the TPP/CPTPP and the RCEP reflect the ongoing policy dilemma confronting intellectual property policymakers in the region. If the protection and enforcement standards are set too low, the participating countries will have squandered a rare and valuable opportunity to promote regional harmonisation. If the standards are set too high, however, they will also have hurt themselves

127 Matthew P Goodman 'US Economic Strategy in the Asia-Pacific Region: Promoting Growth, Rules, and Presence' in Tang Guoqiang and Peter A Petri (eds) New Directions in Asia-Pacific Economic Integration (East-West Center, Honolulu, 2014) 169 at 174-175; Lewis, above n 24, at 235; Robert Scollay 'The TPP and RCEP: Prospects for Convergence' in Tang Guoqiang and Peter A Petri (eds) New Directions in Asia-Pacific Economic Integration (East-West Center, Honolulu, 2014) 235 at 235. 128 Campbell, above n 73, at 193.

129 Ann Capling and John Ravenhill 'The TPP: Multilateralizing Regionalism or the Securitization of Trade Policy' in CL Lim, Deborah Kay Elms and Patrick Low (eds) The Trans-Pacific Partnership: A Quest for a Twenty-First Century Trade Agreement (Cambridge University Press, Cambridge, 2012) 279 at 293 (doi.org/10.1017/CBO9781139236775.025); Ellen L Frost 'China's Commercial Diplomacy in Asia: Promise or Threat?' in William W Keller and Thomas G Rawski (eds) China's Rise and the Balance of Influence in Asia (University of Pittsburgh Press, Pittsburgh, 2007) 95 at 105; David Shambaugh 'Introduction: The Rise of China and Asia's New Dynamics' in David Shambaugh (ed) Power Shift: China and Asia's New Dynamics (University of California Press, Berkeley, 2006) 1 at 17; Yu, above $\mathrm{n} 33$, at 1151 .

130 Lewis, above n 24, at 235; Lewis, above n 118, at 369-370; Yu, above n 33, at 1177. 
by impeding future development, eroding global competitiveness and jeopardising access to essential medicines, educational materials and information technology.

To complicate matters even further, the TPP chapter, the chapter as modified by the CPTPP and the draft RCEP chapter all feature protection and enforcement standards that have already been widely accepted by the developed country members of the Asian Pacific region. Overemphasis on these standards can be problematic, as such emphasis could undermine the region's ability to undertake the reform needed to target problems that are commonly found in developing countries. Indeed, except for those concerning the protection of genetic resources, traditional knowledge and traditional cultural expressions, none of the intellectual property provisions found in the TPP Agreement, the CPTPP or the draft RCEP chapter seem to target those specific problems.

As I have noted in previous works, developing countries in the Asian Pacific region continue to face a wide array of policy challenges, including a significant discrepancy between law on the books and enforcement on the ground; a woeful lack of access to essential medicines, educational materials, computer software, information technology, scientific and technical knowledge, and patented seeds and foodstuffs; and the growing need for alternative innovation models and other measures to address the highly uneven economic and technological developments within these countries. ${ }^{131}$ If the intellectual property chapters in the TPP Agreement, the CPTPP or the RCEP Agreement will not address these challenges, one has to wonder what other measures will have to be taken to eventually improve the intellectual property systems in the developing country members of the Asian Pacific region. 
This text is taken from Making Copyright Work for the Asian Pacific: Juxtaposing Harmonisation with Flexibility, edited by Susan Corbett and Jessica C Lai, published 2018 by ANU Press, The Australian National University, Canberra, Australia.

doi.org/10.22459/MCWAP.10.2018.01 